\title{
Theoretical Investigation of the Newly Designed Benzimidazole Based Metal Mediated DNA Base Couples with DFT Method
}

\author{
Fatma Sevin*, Mostafa Asghari Dilmani, Kübra Sarıkavak, Samira Farshbaf Jeddi \\ Chemistry Department, Faculty of Science, Hacettepe University, Ankara, Turkey \\ Email: sevin@hacettepe.edu.tr
}

How to cite this paper: Sevin, F. Dilmani, M.A., Sarkkavak, K. and Jeddi, S.F. (2017) Theoretical Investigation of the Newly Designed Benzimidazole Based Metal Mediated DNA Base Couples with DFT Method. Computational Chemistry, 5, 74-90. https://doi.org/10.4236/cc.2017.52007

Received: February 7, 2017

Accepted: April 27, 2017

Published: April 30, 2017

Copyright ( 92017 by authors and Scientific Research Publishing Inc. This work is licensed under the Creative Commons Attribution International License (CC BY 4.0).

http://creativecommons.org/licenses/by/4.0/

\begin{abstract}
DNA has the genetic information storage and transmission capacity according to the sequential order of the monomer and creates a central role in the chemical evolution by copying itself with the proliferation feature. WatsonCrick base pairs define two base pairs with hydrogen bonds. If metal coordination bonds replace hydrogen bonds more stable alternative metalloDNA sequence can be established. If the replication feature can be obtained for the metallo-DNA, this will greatly benefit the creation of DNA computer keys. In this study, a new type of benzimidazole based metallo-DNA sensors consisting of a connector unit that unsaturated azinil bridge linked to Watson-Crick base pairs with $\mathrm{Ni}^{2+}, \mathrm{Hg}^{2+}, \mathrm{Zn}^{2+}, \mathrm{Ag}^{+}, \mathrm{Pt}^{2+}, \mathrm{Pd}^{2+}$ metal cations and a benzimidazole has been designed. Absorption and emission spectrum of the newly designed aqua medium based fluorophore and their metallo-DNA sensors with selected cations have been theoretically investigated by using DFT method. The logic gates of selected possible sensors which response in the visible region have also been examined in detail in acidic and water phase. As a result of calculated absorption-emission spectrum data show that $\mathrm{T}-\mathrm{Hg}-\mathrm{A}-\mathrm{Bnz}$, A-Ni-T-Bnz, C-Pt-G-Bnz, C-Ni-C-Bnz complexes produce OR gate. T-Zn-T-Bnz and G-Pt-C-Bnz results demonstrated XOR and AND logic gate, respectively.
\end{abstract}

\section{Keywords}

Flourescence, Metallo-DNA Sensor, Benzimidazole, Logic Gates, DFT

\section{Introduction}

Today, development of biomolecular structures is generally based on supramolecules that include non-covalent interactions, such as hydrogen bonds, hydrophobic effects and metal coordination bonds [1] [2] [3] [4]. Without a 
doubt, the most basic structures in origins of the chemical evolution are the nucleic acids. The most basic indicators that allow storing, transferring and copying of the genetic information within these nuclear acids are hydrogen bonded Watson-Crick base pairs. Having metal coordination bonds instead of hydrogen bonds presents alternative and completely different base pairs [5] [6] [7]. As known, the event of binding a metal ion to a molecule affects the characteristics of UV-visible spectrum of molecule. Fluorescence technics are also good tool to identify biomolecular interactions and uses widely in many research. For these technics, some fluorophores have been used to analyze cations and anions that can be found in the nature. Among various fluorophores, benzimidazole has drawn attention due to its optical properties and high stability. Benzimidazole ring is a very good type of fluorophore as it can produce "scorpion type" complexes [8].

Theoretically suggested one dimensional TMn (benzimidazole $)_{n+1}(\mathrm{TM}=\mathrm{Sc}$, $\mathrm{Ti}, \mathrm{V}, \mathrm{Cr}, \mathrm{Mn}$ ) system's electronic and magnetic characteristics were investigated with DFT method [9]. It was detected that benzimidazole can be stable while also retaining the helix and one-dimensional characteristics of the DNA with the $\mathrm{Ti}, \mathrm{V}$ and $\mathrm{Cr}$ transition atoms. Experimentally [10] and theoretically [11] studies were established about structural-electronic characteristics and UV absorption spectrums of the Thymine- $\mathrm{Hg}^{2+}$-Thymine base pair ( T-Hg-T), which is a mercury (II) linked metallo-DNA complex. In the experimental study, the stability of the thymine pair with the mercury ion was determined in various temperatures and $\mathrm{pH}$ 's and it was seen that its maximum absorption was at 260 $\mathrm{nm}$. In the theoretic study, the base pairs and dimers that thymine and its derivatives of cis and trans form with the mercury ion were calculated with the TD-B3LYP and TD-PCM-B3LYP methods, it was determined that maximum absorption occurs in values that are closer to red, which is to say $263 \mathrm{~nm}$ in solvent phase and $276 \mathrm{~nm}$ in gas phase.

Takezawa and Shionoya presented an abstract about the chemistry of metal-linked base pairs which includes primary approaches to the DNA based molecular systems, molecular designs,structures, characteristics and their applications in their research [12]. One of the examples that were provided $\mathrm{Cu}^{2+}$ linked hydroxipyron base pair. The $\mathrm{H}-\mathrm{Cu}^{2+}-\mathrm{H}$ base pair has a square planar characteristic while $\mathrm{H}$ defines a nucleoacid that carries a hydroxipyron. The most distinctive characteristic of the metallo-base pairs added to the DNA is their potential to increase the duplex stability. As expected, metal coordination bond energies are two or three times greater than the hydrogen bonds. For this reason, their stability effects are worked out from the melting temperatures of the DNA base pairs. An example for this is as the following: when there is a $\mathrm{Cu}^{2+}$ ion, this temperature has increased from $37^{\circ}$ Celsius to $50^{\circ}$ Celsius. Similar stabilities are also achieved in Salen-type. Structures like similar to these are synthesized and characterized as monomer structures at first and then they were added to, for example, 15-mer DNA duplexes. Also, Li et al. have examined the aggregation behavior of the silver molecules with the DFT method by using 
polymorphic DNA models that contain Watson-Crick base pairs, i-motif and G-quadrulex [13]. Leutwyler group examined double hydrogen bonded complexes of 2-pyridones cytosine and 1-methyl cytosine with mass, UV and IR spectroscopic techniques and observed five different cytosine 2-pyridone isomers in their theoretical and experimental study [14].

Usage of sensors as logic gates in biochemical researches has begun only recently, but it has started developing [15] [16]. In chemical logic systems, binding a guest molecule to the host molecule corresponds to a logical input and the result includes physical changes as an output which corresponds to absorption or fluorescence spectrum. Whenever multiple chemical inputs provide a single output independent of each other, the system is defined as OR logic gates, which is to say that this is a very weak chemical selection system. On the other hand, AND logic gate identifies multiple chemical inputs based on luck and it provides an input that requires high chemical selectivity.

In this study, metallo-DNA sensors that have new fluorescent characteristics and the capability to work in aqueous mediums have been designed by binding metals $\left(\mathrm{Hg}^{2+}, \mathrm{Ag}^{+}, \mathrm{Ni}^{2+}, \mathrm{Pb}^{2+}, \mathrm{Pt}^{2+}, \mathrm{Zn}^{2+}\right)$ that can provide them coordination, especially planar coordination, to Watson-Crick base pairs and their reversible and changeable optical characteristics in acidic mediums have been investigated and possible logic gates have been suggested. As it can be seen on Figure 1 and Figure 2, a new type of benzimidazole based metallo-DNA base pair sensors have been designed which consisting of a connector unit and unsaturated azinil bridge linked to Watson-Crick ( $\mathrm{T}=$ Thymine, $\mathrm{A}=$ Adenine, $\mathrm{C}=$ Cytosine and $\mathrm{G}$ = Guanine) base pairs bonded with $\mathrm{Ni}^{2+}, \mathrm{Hg}^{2+}, \mathrm{Zn}^{2+}, \mathrm{Ag}^{+}, \mathrm{Pt}^{2+}, \mathrm{Pd}^{2+}$ metal cations and a fluorophore. These newly designed metallo-sensors have the characteristic that allows molecular identification with visible changes in color (colorimeter) and increases and decreases in emission wavelength (fluorescence) due to their coordination with various cations.

To explain the structural and electronic characteristics of these sensors in different media, their energies, absorption and emission spectrums, energy

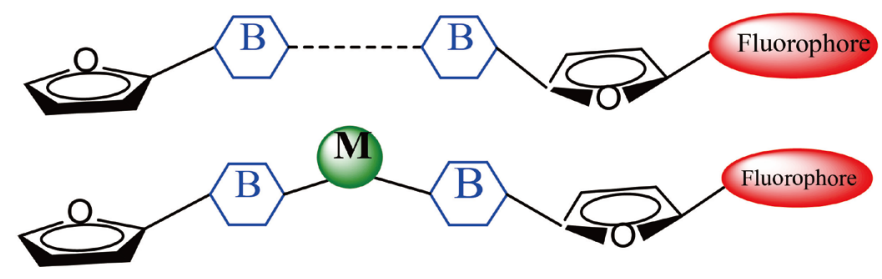

B: T-T, A-T, T-A, C-G, G-C, C-C M: $\mathrm{Hg}^{+2}, \mathrm{Zn}^{+2}, \mathrm{Ag}^{+}, \mathrm{Ni}^{+2}, \mathrm{Pd}^{+2}$ ve $\mathrm{Pt}^{+2}$

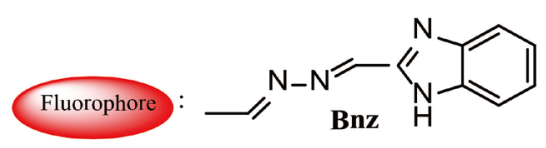

A:<smiles>Nc1ncnc2[nH]cnc12</smiles>

$\mathrm{C}:$<smiles>Cc1c[nH]c(=O)n1N</smiles>

$\mathrm{G}:$<smiles>Nc1nc2[nH]cnc2c(=O)[nH]1</smiles>

$\mathrm{T}:$<smiles></smiles>

Figure 1. Designed benzimidazole based metallo-DNA based pair sensors. 


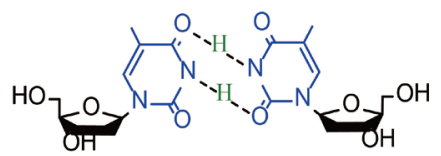

T-T

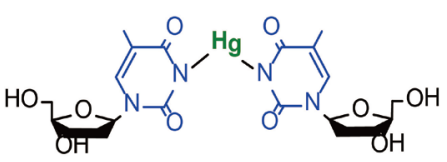

$$
\mathrm{T}-\mathrm{Hg}_{\mathrm{g}} \mathrm{T}
$$

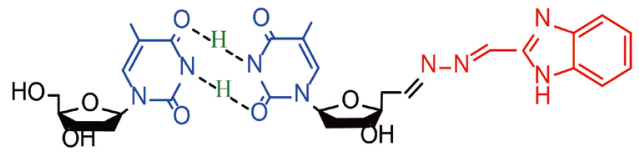

T-T-Bnz

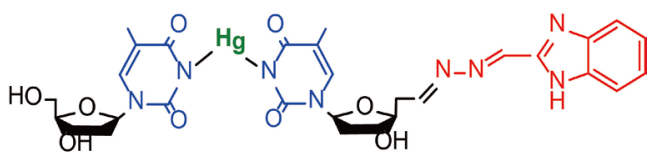

$\mathrm{T}-\mathrm{Hg}-\mathrm{T}-\mathrm{Bnz}$

Figure 2. Some azinil benzimidazole mediated tymine base pair examples.

differences between frontier molecular orbitals (HOMO: highest occupied molecular orbital and LUMO: lowest unoccupied molecular orbital) which means HOMO-LUMO gap has been calculated as well as color and emission changes. Same calculations have been made with protonation of sp2 hybrid nitrogen atom of benzimidazole portions and logic gates have been presented for acidic medium and aqueous phase. As a result, since these designed sensors are expected to be potential keys for the DNA computer technology, we expect them to contribute greatly to science and technology applications.

\section{Method}

In this study, all the calculations have been performed with Gaussian 09W [17] and GaussView 5.0.8 molecular modeling software [18]. The methods used in the calculation of the organometallic compounds with mercury in the literature have been chosen [19] [20] [21]. It is especially known, M06 is one of the best functional for the study of organometallic and inorganomatellic thermochemistry and noncovalent interactions. In the frame of these informationsM06 (Hybrid meta exchange-correlation functionals) [22], B3LYP (Becke, three-parameter, Lee-Yang-Parr) [23], PBE0 (Perdew, Burke and Ernzerhof) [24] methods and the double-zeta pseudo-potential LandL2DZ [25] basis set has been selected for geometry optimization and evaluate the absorption and emission spectroscopy. The selection of appropriate method among the aforecited methods has been based on the experimental results of $\mathrm{T}-\mathrm{Hg}^{2+}-\mathrm{T}$ base pair which has a known maximum absorption value in the literature as $260 \mathrm{~nm}$. These calculated absorption results have been compared with the corresponding experimental values. The calculation results show that M06 functional has been found better than the other methods as in Table S1 (it is given in Supporting info). After determining the appropriate method, all subsequent calculations performed with M06 functional LandL2DZ basis set. Vibrational frequency analyses have been carried out to confirm local minima of the structures. In order to compute the solvation effect self-consistent reaction field (SCRF) theory with polarizable continuum method (PCM) used in the water phase calcultaions. The dielectric constant was chosen as the standard value for water, $(\varepsilon=78.39)$. Calculations 
corresponding to acidic medium implemented with nitrogen protonation of benzimizadole fragment. Absorption and emission spectra calculated and logic gates determined through these constructions.

The total energy of the structures (E), Gibbs free energy $(\mathrm{G})$ and enthalpy $(\mathrm{H})$ has been calculated. Along with gas phase calculation, Conductor-Like Screening Model [26] has been used to calculate theoretical absorption wavelength in aqueous media. Also, 7-digit TD-DFT method has been used for emission calculation [27].

\section{Results and Discussion}

Investigation of the DNA bases and their structures with metal and benzimidazole has been divided into two categories as T-A, A-T, C-G and G-C base combinations. All calculations have been conducted in the water phase. Formation energies, frontier molecular orbital band gaps have been calculated and studies particularly have focused on the photophysical properties.

\subsection{Properties of Designed T-T and T-A and T-A Base Pairs and Their Benzimidazole Base Pairs with and without Metal Cations}

In the first stage, the complexation energies of T-T, T-A and A-T base pairs with metal cations have been calculated and obtained results given in Table 1. Also, total energies and entaphy have been demonstrated in Tables S2-S4. Complexation energies of benzimidazole (Bnz) based T-T,T-A and A-T base pairs with metal cations have been calculated and results given in the same table. As can be seen from the table, complexation of $\mathrm{T}-\mathrm{T}$ occurs easily with $\mathrm{Ni}^{2+}$. This sequence followed by $\mathrm{Hg}^{2+}$. The complexation abilities of metal cation in this sequence for $\mathrm{T}-\mathrm{T}$ is $\mathrm{Ni}^{2+}>\mathrm{Hg}^{2+}>\mathrm{Zn}^{2+}>\mathrm{Ag}^{+}>\mathrm{Pt}^{2+}>\mathrm{Pd}^{2+}$. This sequence is the

Table 1. The complexation energies of T-T, T-A and A-T base pairs with metal cations and Bnz (Kcal/mol).

\begin{tabular}{|c|c|c|c|c|c|}
\hline \multirow{2}{*}{ Base Pairs } & \multicolumn{4}{|c|}{ Energy Values } & \\
\hline & $\Delta \mathrm{G}$ & Base Pairs & $\Delta \mathrm{G}$ & Base Pairs & \\
\hline $\mathrm{T}-\mathrm{T} \rightarrow \mathrm{T}-\mathrm{Hg}-\mathrm{T}$ & -122.66 & $\mathrm{~T}-\mathrm{A} \rightarrow \mathrm{T}-\mathrm{Hg}-\mathrm{A}$ & -101.32 & & \\
\hline $\mathrm{T}-\mathrm{T} \rightarrow \mathrm{T}-\mathrm{Zn}-\mathrm{T}$ & -98.06 & $\mathrm{~T}-\mathrm{A} \rightarrow \mathrm{T}-\mathrm{Zn}-\mathrm{A}$ & -81.46 & & \\
\hline $\mathrm{T}-\mathrm{T} \rightarrow \mathrm{T}-\mathrm{Ag}-\mathrm{T}$ & -78.26 & $\mathrm{~T}-\mathrm{A} \rightarrow \mathrm{T}-\mathrm{Ag}-\mathrm{A}$ & -72.19 & & \\
\hline $\mathrm{T}-\mathrm{T} \rightarrow \mathrm{T}-\mathrm{Ni}-\mathrm{T}$ & -183.55 & $\mathrm{~T}-\mathrm{A} \rightarrow \mathrm{T}-\mathrm{Ni}-\mathrm{A}$ & -134.85 & & \\
\hline $\mathrm{T}-\mathrm{T} \rightarrow \mathrm{T}-\mathrm{Pd}-\mathrm{T}$ & -59.08 & $\mathrm{~T}-\mathrm{A} \rightarrow \mathrm{T}-\mathrm{Pd}-\mathrm{A}$ & -50.00 & & \\
\hline $\mathrm{T}-\mathrm{T} \rightarrow \mathrm{T}-\mathrm{Pt}-\mathrm{T}$ & -71.98 & $\mathrm{~T}-\mathrm{A} \rightarrow \mathrm{T}-\mathrm{Pt}-\mathrm{A}$ & -61.35 & & \\
\hline $\mathrm{T}-\mathrm{A}-\mathrm{Bnz} \rightarrow \mathrm{T}-\mathrm{Hg}-\mathrm{A}-\mathrm{Bnz}$ & 96.05 & $\mathrm{~A}-\mathrm{T}-\mathrm{Bnz} \rightarrow \mathrm{A}-\mathrm{Hg}-\mathrm{T}-\mathrm{Bnz}$ & -105.22 & $\mathrm{~T}-\mathrm{T}-\mathrm{Bnz} \rightarrow \mathrm{T}-\mathrm{Hg}-\mathrm{T}-\mathrm{Bnz}$ & -112.08 \\
\hline $\mathrm{T}-\mathrm{A}-\mathrm{Bnz} \rightarrow \mathrm{T}-\mathrm{Zn}-\mathrm{A}-\mathrm{Bnz}$ & -77.00 & $\mathrm{~A}-\mathrm{T}-\mathrm{Bnz} \rightarrow \mathrm{A}-\mathrm{Zn}-\mathrm{T}-\mathrm{Bnz}$ & -84.92 & $\mathrm{~T}-\mathrm{T}-\mathrm{Bnz} \rightarrow \mathrm{T}-\mathrm{Zn}-\mathrm{T}-\mathrm{Bnz}$ & -99.02 \\
\hline $\mathrm{T}-\mathrm{A}-\mathrm{Bnz} \rightarrow \mathrm{T}-\mathrm{Ag}-\mathrm{A}-\mathrm{Bnz}$ & -64.22 & $\mathrm{~A}-\mathrm{T}-\mathrm{Bnz} \rightarrow \mathrm{A}-\mathrm{Ag}-\mathrm{T}-\mathrm{Bnz}$ & -76.00 & $\mathrm{~T}-\mathrm{T}-\mathrm{Bnz} \rightarrow \mathrm{T}-\mathrm{Ag}-\mathrm{T}-\mathrm{Bnz}$ & -79.37 \\
\hline $\mathrm{T}-\mathrm{A}-\mathrm{Bnz} \rightarrow \mathrm{T}-\mathrm{Ni}-\mathrm{A}-\mathrm{Bnz}$ & -122.41 & $\mathrm{~A}-\mathrm{T}-\mathrm{Bnz} \rightarrow \mathrm{A}-\mathrm{Ni}-\mathrm{T}-\mathrm{Bnz}$ & -104.55 & $\mathrm{~T}-\mathrm{T}-\mathrm{Bnz} \rightarrow \mathrm{T}-\mathrm{Ni}-\mathrm{T}-\mathrm{Bnz}$ & -184.62 \\
\hline $\mathrm{T}-\mathrm{A}-\mathrm{Bnz} \rightarrow \mathrm{T}-\mathrm{Pd}-\mathrm{A}-\mathrm{Bnz}$ & -45.89 & $\mathrm{~A}-\mathrm{T}-\mathrm{Bnz} \rightarrow \mathrm{A}-\mathrm{Pd}-\mathrm{T}-\mathrm{Bnz}$ & -54.02 & $\mathrm{~T}-\mathrm{T}-\mathrm{Bnz} \rightarrow \mathrm{T}-\mathrm{Pd}-\mathrm{T}-\mathrm{Bnz}$ & -60.81 \\
\hline $\mathrm{T}-\mathrm{A}-\mathrm{Bnz} \rightarrow \mathrm{T}-\mathrm{Pt}-\mathrm{A}-\mathrm{Bnz}$ & -56.00 & $\mathrm{~A}-\mathrm{T}-\mathrm{Bnz} \rightarrow \mathrm{A}-\mathrm{Pt}-\mathrm{T}-\mathrm{Bnz}$ & -67.26 & $\mathrm{~T}-\mathrm{T}-\mathrm{Bnz} \rightarrow \mathrm{T}-\mathrm{Pt}-\mathrm{T}-\mathrm{Bnz}$ & -73.26 \\
\hline
\end{tabular}


same with T-T for T-A base pair, too.

Complexation of benzimidazole with $\mathrm{T}-\mathrm{T}$ base pair and its complexation energies with metal cations prefers the $\mathrm{Ni}^{2+}$ cation. Its sequence is as following: $\mathrm{Ni}^{2+}>\mathrm{Hg}^{2+}>\mathrm{Zn}^{2+}>\mathrm{Ag}^{+}>\mathrm{Pt}^{2+}>\mathrm{Pd}^{2+}$. T-A-Bnz base pair shows the same trend. This sequence is the same as $\mathrm{T}-\mathrm{T}$ and benzimidazole did not have an impact on adenine.

It is clearly observed from the results, benzimidazole based A-T designed base pair results show that when benzimidazole bonds with the thymine part of this base pair, the first two rows of the sequence slightly changes: $\mathrm{Hg}^{2+}>\mathrm{Ni}^{2+}>$ $\mathrm{Zn}^{2+}>\mathrm{Ag}^{+}>\mathrm{Pt}^{2+}>\mathrm{Pd}^{2+}$. It can be considered that benzimidazole has more effects on thymine. The result shows that, with the exception of the A-T-Bnz base pair which prefers $\mathrm{Hg}^{2+}$ cation, other benzimidazole based DNA base pairs primarily prefer $\mathrm{Ni}^{2+}$ cation.

The energy gap reflects the reactivity or stability of the molecule. HOMOLUMO energy gap of molecules is considered as a measure of charge transfer and is regarded as an important parameter in determining the properties such as electrical conductivity. Table 2 shows that T-T-Bnz has made it stable than T-T about $0.35 \mathrm{eV}$. However, in case of complexation with metal cations, $\mathrm{Pd}^{2+}$ and $\mathrm{Pt}^{2+}$ is more thermodynamically stable while the gap energies of other metal cations decrease. This situation shows that conjugation is also increased on the structure. The highest amount conjugation occurs with $\mathrm{Ni}^{2+}$ and $\mathrm{Ag}^{+}$among the selected cations. Hence, HUMO-LUMOs of T-Ag-T seen that the contribution of metal orbitals is greater in linked benzimidazole and conjugation shifts to benzimidazole ring. The significant effect has not been observed by linking benzimidazole for $\mathrm{T}$-A base pairs. Complexation energies with $\mathrm{Pd}^{2+}$ and $\mathrm{Pt}^{2+}$ metal cations are higher than the cations for $\mathrm{T}-\mathrm{A}$ and also with $\mathrm{Hg}^{2+}$ and $\mathrm{Zn}^{2+}$ cations are decreased their gap energies. In terms of A-T base pairs, bonding of benzimidazole to structure increases molecular stability about $0.20 \mathrm{eV}$. Although $\mathrm{Ag}^{+}$and $\mathrm{Ni}^{2+}$ cations more stable in case of complexation with metal cations, the energy gap values have decreased only for $\mathrm{Hg}^{2+}$ cation. Thus, base pair orbitals in T-Hg-T HOMO-LUMOs show benzimidazole orbitals in LUMO when benzimi-

Table 2. The HOMO-LUMO band gap energies of T-T-, T-A and their complexes with Bnz metal cations (eV).

\begin{tabular}{|c|c|c|c|c|c|c|c|}
\hline \multirow{2}{*}{ Base Pairs } & \multicolumn{7}{|c|}{ HOMO-LUMO gap energies } \\
\hline & - & $\mathrm{Hg}$ & $\mathrm{Zn}$ & $\mathrm{Ag}$ & $\mathrm{Ni}$ & $\mathrm{Pd}$ & $\mathrm{Pt}$ \\
\hline $\mathrm{T}-\mathrm{T}$ & 1.178 & 4.602 & 4.124 & 4.736 & 4.649 & 0.824 & 0.926 \\
\hline T-T-Bnz & 1.552 & 3.050 & 3.107 & 3.009 & 3.013 & 0.912 & 2.354 \\
\hline T-T/T-T-Bnz & -0.347 & 1.552 & 1.017 & 1.727 & 1.636 & -0.088 & -1.428 \\
\hline $\mathrm{T}-\mathrm{A}$ & 0.940 & 3.432 & 3.785 & 3.230 & 3.263 & 3.395 & 3.671 \\
\hline T-A-Bnz & 0.980 & 1.413 & 1.392 & 4.565 & 4.763 & 4.680 & 4.884 \\
\hline T-A/T-A-Bnz & -0.040 & 2.019 & 2.393 & -1.335 & -1.500 & -1.285 & -1.213 \\
\hline$A-T$ & 0.940 & 3.432 & 3.785 & 3.230 & 3.263 & 3.395 & 3.671 \\
\hline A-T-Bnz & 1.139 & 1.337 & 4.372 & 4.566 & 4.120 & 3.517 & 4.227 \\
\hline A-T/A-T-Bnz & -0.199 & 2.095 & -0.587 & -1.336 & -0.857 & -0.122 & -0.556 \\
\hline
\end{tabular}


Table 3. Maximum absorption/emission wavelength (nm) and differences between them of the designed T-T, T-A, A-T pairs and their Bnz complexes.

\begin{tabular}{|c|c|c|c|c|c|c|c|c|c|c|c|}
\hline \multirow{2}{*}{ Pairs } & \multicolumn{5}{|c|}{ T-T-Based } & \multicolumn{6}{|c|}{ T-T-Bnz Based } \\
\hline & $\lambda \mathrm{Abs}$ & Osc & $\lambda \mathrm{Ems}$ & Osc & $\Delta \lambda$ & Pairs $\lambda$ & & Osc & $\lambda \mathrm{Ems}$ & Osc & $\Delta \lambda$ \\
\hline T-Hg-T & 335 & 0.230 & 397 & 0.110 & 43 & T-Hg-T-Bnz & 358 & 0.560 & 407 & 0.380 & 49 \\
\hline $\mathrm{T}-\mathrm{Zn}-\mathrm{T}$ & 460 & 0.100 & 471 & 0.080 & 10 & $\mathrm{~T}-\mathrm{Zn}-\mathrm{T}-\mathrm{Bnz}$ & 468 & 0.009 & 482 & 0.005 & 13 \\
\hline T-Ni-T & 283 & 0.004 & 314 & 0.001 & 31 & T-Ni-T-Bnz & 331 & 0.046 & 359 & 0.019 & 105 \\
\hline T-Pd-T & 866 & 0.003 & 901 & 0.001 & 34 & T-Pd-T-Bnz & 967 & 0.001 & 1109 & 0.008 & 141 \\
\hline \multirow[t]{2}{*}{$\mathrm{T}-\mathrm{Pt}-\mathrm{T}$} & 603 & 0.025 & 738 & 0.013 & 13 & T-Pt-T-Bnz & 807 & 0.078 & 921 & 0.047 & 113 \\
\hline & & \multicolumn{5}{|c|}{ T-A-Based } & \multicolumn{5}{|c|}{ T-A-Bnz Based } \\
\hline $\mathrm{T}-\mathrm{Hg}-\mathrm{A}$ & 473 & 0.047 & 509 & 0.044 & 35 & T-Hg-A-Bnz & 468 & 0.019 & 509 & 0.016 & 41 \\
\hline $\mathrm{T}-\mathrm{Zn}-\mathrm{A}$ & 602 & 0.051 & 668 & 0.040 & 65 & T-Zn-A-Bnz & 692 & 0.029 & 715 & 0.017 & 23 \\
\hline T-Ag-A & 645 & 0.088 & 861 & 0.082 & 216 & T-Ag-A-Bnz & 781 & 0.067 & 898 & 0.056 & 116 \\
\hline T-Ni-A & 343 & 0.027 & 457 & 0.023 & 114 & T-Ni-A-Bnz & 351 & 0.004 & 477 & 0.003 & 126 \\
\hline T-Pd-A & 864 & 0.002 & 985 & 0.001 & 121 & T-Pd-A-Bnz & 986 & 0.058 & 1108 & 0.054 & 121 \\
\hline \multirow[t]{2}{*}{ T-Pt-A } & 767 & 0.700 & 789 & 0.650 & 21 & T-Pt-A-Bnz & 801 & 0.061 & 827 & 0.540 & 26 \\
\hline & & \multicolumn{5}{|c|}{ A-T-Based } & \multicolumn{5}{|c|}{ A-T-Bnz Based } \\
\hline $\mathrm{A}-\mathrm{T}$ & 301 & 0.030 & 339. & 0.028 & 38 & $\mathrm{~A}-\mathrm{T}-\mathrm{Bnz}$ & 365 & 0.013 & 404 & 0.012 & 38 \\
\hline A-Hg-T & 473 & 0.047 & 509 & 0.044 & 35 & A-Hg-T-Bnz & 439 & 0.019 & 488 & 0.014 & 48 \\
\hline A-Zn-T & 602 & 0.051 & 668 & 0.040 & 65 & A-Zn-T-Bnz & 658 & 0.020 & 670 & 0.018 & 12 \\
\hline A-Ni-T & 343 & 0.027 & 457 & 0.023 & 114 & A-Ni-T-Bnz & 443 & 0.002 & 661 & 0.002 & 217 \\
\hline A-Pd-T & 864 & 0.002 & 985 & 0.001 & 121 & A-Pd-T-Bnz & 822 & 0.001 & 1043 & 0.001 & 221 \\
\hline A-Pt-T & 767 & 0.700 & 789 & 0.650 & 21 & A-Pt-T-Bnz & 789 & 0.670 & 839 & 0.590 & 40 \\
\hline
\end{tabular}

dazole enters. According to calculations; $\mathrm{Hg}^{2+}, \mathrm{Ag}^{+}$and $\mathrm{Zn}^{2+}$ cations can increase resonance stability of structure and $\mathrm{Pt}^{2+}$ and $\mathrm{Pd}^{2+}$ cations provides thermodynamic stability.

In the scope of this section, absorption and emission spectrum has been studied and results of the complexes formed by T-T, T-A, A-T bases and their benzimidazole based pairs with metals has been given in Table 3. This table shows that T-T-Bnz and T-M-T complexes have maximum absorption and emission wavelength $\left(\lambda_{\max }\right)$ with $\mathrm{Zn}^{2+}$ and $\mathrm{Ag}^{+}$cations, respectively. For $\mathrm{Ag}^{+}$ cations, Stokes shift value are greater than $\mathrm{Zn}^{2+}$ cations. When the results are evaluated for T-A and T-A-Bnz, it has seen that maximum absorption and emission wavelength $\lambda_{\max }$ values belong to T-Hg-A, T-Zn-A and T-Zn-A-Bnz complexes. $\Delta \lambda$ value of the $\mathrm{T}$-A based complex with $\mathrm{Ni}^{2+}$ cations is higher than $\mathrm{Hg}^{2+}$ cations one. The results obtained by A-T based structures are the same with the obtained for T-A structure. Maximum absorption and emission wavelength for A-T-Bnz belong to the A-Zn-T-Bnz complex

In accordance with spectral data of T-T, T-A, A-T base pairs with selected 
metals and benzimidazole their colors have been determined before and after radiation. The color difference caused by the binding of metal cations to T-T and T-T-Bnz structures is given in the Table S5. The color change from blue to green has been observed in T-Hg-A, T-Zn-T-Bnz, A-Hg-T and T-Hg-A-Bnz complexes. The color change from violet to green has been seen in A-Hg-T-Bnz and A-Ni-T-Bnz pairs. Yellow coloured T-Ag-T and orange coloured T-Pt-T base pairs has losts their colours after radiation like red coloured $\mathrm{T}-\mathrm{Ag}-\mathrm{A}$, T-Zn-A-Bnz and A-Ag-T pairs. T-Ni-A, T-Ni-A-Bnz and A-Ni-T complexes that are colourless initially,have gained blue colour after radiation. Colorless A-T-Bnz and T-Hg-T-Bnz pairs have gained violet colour, too. The color change from yellow to red has been observed for T-Ag-T and A-Zn-T pairs

\subsection{Properties of Designed C-G and G-C Base Pairs and Their Benzimidazole Base Pairs with and without Metal Cations}

As in the previous section, complexation energies, band gaps and spectral properties of the targeted structures has been studied in this part, too. Table 4 displays complexation energies of $\mathrm{C}-\mathrm{G}$ and $\mathrm{C}-\mathrm{C}$ base pairs and their combinations with benzimidazole and selected cations.

Calculations show that the complexation of $\mathrm{C}-\mathrm{G}$ and $\mathrm{C}-\mathrm{C}$ occurs easily with $\mathrm{Ni}^{2+}$ like T-T and A-T ba-ses. The metal cation sequence for C- $\mathrm{G}$ is $\mathrm{Ni}^{2+}>\mathrm{Hg}^{2+}>$ $\mathrm{Pt}^{2+}>\mathrm{Pd}^{2+}>\mathrm{Ag}^{+}>\mathrm{Zn}^{2+}$. The metal cation sequence for $\mathrm{C}-\mathrm{C}$ is $\mathrm{Ni}^{2+}>\mathrm{Ag}^{+}>$ $\mathrm{Hg}^{2+}>\mathrm{Zn}^{2+}>\mathrm{Pd}^{2+}>\mathrm{Pt}^{2+}$. Unlike the others, this sequence is followed by $\mathrm{Ag}^{+}$. When the complexation energies analyzed for created by complexation of Bnz based C-G pairs with metal cations, it has been seen that the bonding of Bnz with guanine is the same as its bonding with G-C base pair and this has not changed the preference of it. The same results have been obtained for G-C-Bnz complex and C-C-Bnz complex. The results of all the complexation calculations

Table 4. The complexation energies of C-G -Bnz and G-C-Bnz base pairs with metal cations (Kcal/mol).

\begin{tabular}{|c|c|c|c|c|c|}
\hline \multirow{2}{*}{ Base Pairs } & \multicolumn{4}{|c|}{ Energy Values } & \\
\hline & $\Delta \mathrm{G}$ & Base Pairs & $\Delta \mathrm{G}$ & Base Pairs & \\
\hline $\mathrm{C}-\mathrm{G} \rightarrow \mathrm{C}-\mathrm{Hg}-\mathrm{G}$ & -140.33 & $\mathrm{C}-\mathrm{C} \rightarrow \mathrm{C}-\mathrm{Hg}-\mathrm{C}$ & -91.33 & C-G-Bnz $\rightarrow$ C-Hg-G-Bnz & \\
\hline $\mathrm{C}-\mathrm{G} \rightarrow \mathrm{C}-\mathrm{Zn}-\mathrm{G}$ & -63.55 & $\mathrm{C}-\mathrm{C} \rightarrow \mathrm{C}-\mathrm{Zn}-\mathrm{C}$ & -82.22 & $\mathrm{C}-\mathrm{G}-\mathrm{Bnz} \rightarrow \mathrm{C}-\mathrm{Zn}-\mathrm{G}-\mathrm{Bnz}$ & \\
\hline $\mathrm{C}-\mathrm{G} \rightarrow \mathrm{C}-\mathrm{Ag}-\mathrm{G}$ & -77.77 & $\mathrm{C}-\mathrm{C} \rightarrow \mathrm{C}-\mathrm{Ag}-\mathrm{C}$ & -94.27 & C-G-Bnz $\rightarrow$ C-Ag-G-Bnz & \\
\hline $\mathrm{C}-\mathrm{G} \rightarrow \mathrm{C}-\mathrm{Ni}-\mathrm{G}$ & -154.64 & $\mathrm{C}-\mathrm{C} \rightarrow \mathrm{C}-\mathrm{Ni}-\mathrm{C}$ & -110.01 & C-G-Bnz $\rightarrow$ C-Ni-G-Bnz & \\
\hline $\mathrm{C}-\mathrm{G} \rightarrow \mathrm{C}-\mathrm{Pd}-\mathrm{G}$ & -101.04 & $\mathrm{C}-\mathrm{C} \rightarrow \mathrm{C}-\mathrm{Pd}-\mathrm{C}$ & -80.00 & C-G-Bnz $\rightarrow$ C-Pd-G-Bnz & \\
\hline $\mathrm{C}-\mathrm{G} \rightarrow \mathrm{C}-\mathrm{Pt}-\mathrm{G}$ & -113.36 & $\mathrm{C}-\mathrm{C} \rightarrow \mathrm{C}-\mathrm{Pt}-\mathrm{C}$ & -79.88 & C-G-Bnz $\rightarrow$ C-Pt-G-Bnz & \\
\hline $\mathrm{G}-\mathrm{C}-\mathrm{Bnz} \rightarrow \mathrm{G}-\mathrm{Hg}-\mathrm{CBnz}$ & -132.45 & $\mathrm{C}-\mathrm{C}-\mathrm{Bnz} \rightarrow \mathrm{C}-\mathrm{Hg}-\mathrm{CBnz}$ & -132.45 & C-G-Bnz $\rightarrow$ C-Hg-G-Bnz & -125.05 \\
\hline G-C-Bnz $\rightarrow$ G-Zn-C-Bnz & -69.01 & C-C-Bnz $\rightarrow$ C-Zn-C-Bnz & -69.01 & C-G-Bnz $\rightarrow$ C-Zn-G-Bnz & -61.04 \\
\hline $\mathrm{G}-\mathrm{C}-\mathrm{Bnz} \rightarrow \mathrm{G}-\mathrm{Ag}-\mathrm{C}-\mathrm{Bnz}$ & -81.34 & $\mathrm{C}-\mathrm{C}-\mathrm{Bnz} \rightarrow \mathrm{C}-\mathrm{Ag}-\mathrm{C}-\mathrm{Bnz}$ & -81.34 & C-G-Bnz $\rightarrow$ C-Ag-G-Bnz & -73.24 \\
\hline G-C-Bnz $\rightarrow$ G-Ni-C-Bnz & -150.09 & $\mathrm{C}-\mathrm{C}-\mathrm{Bnz} \rightarrow \mathrm{C}-\mathrm{Ni}-\mathrm{C}-\mathrm{Bnz}$ & -150.09 & C-G-Bnz $\rightarrow$ C-Ni-G-Bnz & -147.69 \\
\hline G-C-Bnz $\rightarrow$ G-Pd-C-Bnz & -99.58 & $\mathrm{C}-\mathrm{C}-\mathrm{Bnz} \rightarrow \mathrm{C}-\mathrm{Pd}-\mathrm{C}-\mathrm{Bnz}$ & -99.58 & C-G-Bnz $\rightarrow$ C-Pd-G-Bnz & -94.26 \\
\hline G-C-Bnz $\rightarrow$ G-Pt-C-Bnz & -110.78 & C-C-Bnz $\rightarrow$ C-Pt-C-Bnz & -110.78 & C-G-Bnz $\rightarrow$ C-Pt-G-Bnz & -104.97 \\
\hline
\end{tabular}


Table 5. The HOMO-LUMO band gap energies of C-G, C-C and their complexes with Bnz and metal cations (eV).

\begin{tabular}{|c|c|c|c|c|c|c|c|}
\hline \multirow{2}{*}{ Base Pairs } & \multicolumn{7}{|c|}{ HOMO-LUMO gap energies } \\
\hline & - & $\mathrm{Hg}$ & $\mathrm{Zn}$ & $\mathrm{Ag}$ & $\mathrm{Ni}$ & $\mathrm{Pd}$ & $\mathrm{Pt}$ \\
\hline $\mathrm{C}-\mathrm{G}$ & 1.573 & 1.629 & 3.198 & 1.201 & 1.814 & 2.329 & 0.825 \\
\hline C-G-Bnz & 0.973 & 0.630 & 3.489 & 2.708 & 2.046 & 3.470 & 3.476 \\
\hline C-G/C-G-Bnz & 0.600 & 0.999 & -0.291 & -1.507 & -0.232 & -1.141 & -2.651 \\
\hline $\mathrm{G}-\mathrm{C}$ & 1.573 & 1.629 & 3.198 & 1.201 & 1.814 & 2.329 & 0.825 \\
\hline G-C-Bnz & 0.580 & 2.319 & 3.452 & 3.078 & 3.342 & 3.211 & 3.188 \\
\hline G-C/G-C-Bnz & 0.993 & -0.690 & -0.254 & -1.877 & -1.528 & -0.882 & -2.363 \\
\hline $\mathrm{C}-\mathrm{C}$ & 0.829 & 2.377 & 3.800 & 2.977 & 2.993 & 2.979 & 2.998 \\
\hline C-C-Bnz & 0.914 & 2.051 & 3.652 & 2.029 & 2.916 & 3.274 & 2.706 \\
\hline C-C/C-C-Bnz & -0.085 & 0.326 & 0.148 & 0.948 & 0.077 & -0.295 & 0.292 \\
\hline
\end{tabular}

shows that except for A-T-Bnz base pair which prefers $\mathrm{Hg}^{2+}$ cation, other benzimidazole based $\mathrm{DNA}$ base pairs primarily prefer $\mathrm{Ni}^{2+}$ cation. Also, the HOMO-LUMO band gaps of the molecules can be seen in Table 5. It is observed from Table 5 binding benzimidazole to $\mathrm{C}-\mathrm{G}$ has created $0,60 \mathrm{eV}$ of conjugation andthis effect has been found for the $\mathrm{Hg}^{2+}$ cation while the band gap of other cations has in-creased. The greatest difference has been observed with $\mathrm{Pt}^{2+}$ cation. Binding of $\mathrm{Bnz}$ to G-C provides $0.993 \mathrm{eV}$ of resonance stability. However, when complexation occurs with other metal cations, gap energy values have increased and this value is greater than what is for $\mathrm{Pt}^{2+}$ cation. Binding benzimidazole to $\mathrm{C}-\mathrm{C}$ does not bring about a large effect and it is complexed with any metal cation other than $\mathrm{Pd}^{2+}$, gap energy value decreases and this decrease is greater than the decrease for $\mathrm{Ag}^{+}$. All the results related to band gaps show that resonance stability is increased with $\mathrm{Hg}^{2+}, \mathrm{Ag}^{+}$and $\mathrm{Zn}^{2+}$ while thermodynamic stability is increased with $\mathrm{Pt}^{2+}$ and $\mathrm{Pd}^{2+}$ cations.

The absorption and emission spectrum has been studied and results of the complexes have been formed by C-G, C-G and C-C bases and benzimidazole based pairs with metals have been given in Table 6 .

According to Table 6, maximum absorption and emission wavelength values have been calculated for the $\mathrm{Pt}^{2+}$ cation, which is the most probable cation for both C-M-G and C-M-G-Benzimidazole complexes. The results gathered for G-C based structures are the same with the data which obtained by C-G pair. Examination of the maximum absorption and emission values in the visible area shows that the biggest $\Delta \lambda$ value belongs to the $\mathrm{C}-\mathrm{Ni}-\mathrm{C}$ and $\mathrm{C}-\mathrm{Ni}-\mathrm{C}-\mathrm{Bnz}$ complexes.

Base pairs that show whatsoever colour change has been determined as in the previous section. Colour changes of the base pairs depending on before and after radiation has been presented in Table S9. As can be seen, colour changes of C-M-G and C-M-G-Bnz pairs are same with G-M-C and G-M-C-Bnz pairs because of absorption and emission wavelength of these pairs have equal values. Red coloured C-Hg-C, C-Ag-C and Bnz pairs have disappeared colour. A similar situation has occurred in blue coloured C-Pt-G and violet coloured C-Ni-C base 
Table 6. Maximum absorption/emission wavelength (nm) and differences between them of the designed C-G, G-C, C-Cpairs and their Bnz complexes.

\begin{tabular}{|c|c|c|c|c|c|c|c|c|c|c|c|}
\hline \multirow{2}{*}{ Pairs } & \multicolumn{6}{|c|}{ C-G- Based } & \multicolumn{5}{|c|}{ C-G-Bnz Based } \\
\hline & $\lambda \mathrm{Abs}$ & Osc & $\lambda \mathrm{Ems}$ & Osc & $\Delta \lambda$ & Pairs $\lambda$ & Abs & Osc & $\lambda \mathrm{Ems}$ & Osc & $\Delta \lambda$ \\
\hline C-G & 263 & 0.037 & 294 & 0.020 & 30 & C-G-Bnz & 297 & 0.005 & 310 & 0.005 & 13 \\
\hline C-Hg-G & 324 & 0.024 & 450 & 0.170 & 126 & C-Hg-G-Bnz & 349 & 0.020 & 462 & 0.016 & 112 \\
\hline $\mathrm{C}-\mathrm{Zn}-\mathrm{G}$ & 830 & 0.020 & 1047 & 0.015 & 216 & C-Zn-G-Bnz & 799 & 0.020 & 921 & 0.017 & 122 \\
\hline C-Ag-G & 794 & 0.045 & 815 & 0.030 & 21 & C-Ag-G-Bnz & 743 & 0.038 & 761 & 0.039 & 18 \\
\hline $\mathrm{C}-\mathrm{Ni}-\mathrm{G}$ & 297 & 0.026 & 514 & 0.025 & 217 & C-Ni-G-Bnz & 311 & 0.005 & 735 & 0.004 & 423 \\
\hline C-Pd-G & 473 & 0.026 & 491 & 0.024 & 18 & C-Pd-G-Bnz & 479 & 0.007 & 491 & 0.006 & 11 \\
\hline \multirow[t]{2}{*}{ C-Pt-G } & 454 & 0.029 & 789 & 0.026 & 334 & C-Pt-G-Bnz & 439 & 0.006 & 663 & 0.006 & 194 \\
\hline & \multicolumn{6}{|c|}{ G-C- Based } & \multicolumn{5}{|c|}{ G-C-Bnz Based } \\
\hline $\mathrm{G}-\mathrm{Hg}-\mathrm{C}$ & 324 & 0.024 & 450 & 0.170 & 126 & G-Hg-C-Bnz & 376 & 0.015 & 597 & 0.011 & 220 \\
\hline $\mathrm{G}-\mathrm{Zn}-\mathrm{C}$ & 830 & 0.020 & 1047 & 0.015 & 216 & G-Zn-C-Bnz & 784 & 0.012 & 891 & 0.011 & 107 \\
\hline G-Ag-C & 794 & 0.045 & 815 & 0.030 & 21 & G-Ag-C-Bnz & 718 & 0.081 & 774 & 0.079 & 56 \\
\hline G-Ni-C & 297 & 0.026 & 514 & 0.025 & 217 & G-Ni-C-Bnz & 293 & 0.098 & 417 & 0.086 & 178 \\
\hline G-Pd-C & 473 & 0.026 & 491 & 0.024 & 18 & G-Pd-C-Bnz & 468 & 0.076 & 489 & 0.075 & 21 \\
\hline \multirow[t]{2}{*}{ G-Pt-C } & 454 & 0.029 & 789 & 0.026 & 334 & G-Pt-C-Bnz & 403 & 0.006 & 615 & 0.005 & 212 \\
\hline & \multicolumn{6}{|c|}{ C-C Based } & \multicolumn{5}{|c|}{ C-C-Bnz Based } \\
\hline $\mathrm{C}-\mathrm{C}$ & 398 & 0.001 & 419 & 0.001 & 21 & C-C-Bnz & 343 & 0.001 & 374 & 0.001 & 31 \\
\hline $\mathrm{C}-\mathrm{Hg}-\mathrm{C}$ & 699 & 0.019 & 742 & 0.018 & 42 & C-Hg-C-Bnz & 693 & 0.014 & 711 & 0.012 & 18 \\
\hline C-Zn-C & 778 & 0.002 & 797 & 0.002 & 18 & C-Zn-C-Bnz & 722 & 0.003 & 775 & 0.002 & 52 \\
\hline $\mathrm{C}-\mathrm{Ni}-\mathrm{C}$ & 403 & 0.014 & 729 & 0.012 & 326 & C-Ni-C-Bnz & 414 & 0.016 & 635 & 0.012 & 220 \\
\hline C-Pd-C & 775 & 0.017 & 892 & 0.011 & 117 & C-Pd-C-Bnz & 751 & 0.008 & 860 & 0.005 & 108 \\
\hline C-Pt-C & 786 & 0.086 & 802 & 0.070 & 16 & C-Pt-C-Bnz & 769 & 0.023 & 781 & 0.021 & 11 \\
\hline
\end{tabular}

pairs. Blue-green change exhibited in C-Pd-G and its benzimidazole pair. Violet coloured C-Pt-G-Bnz, G-Pt-C-Bnz and C-Ni-C-Bnz pairs have changed their colours to red, orange and again orange, respectively. Colourless pairs $\mathrm{C}-\mathrm{Hg}-\mathrm{G}$ and its Bnz pair has turned their colour to blue while C-Ni-G green.

\subsection{Logic Gates}

The most probable DNA base pairs with and without metal cations that could be demonstrate Stokes shift has been selected for logic gate calculations. Acidic media effect is included by the protonation of the nitrogen atom on benzimidazole fragment. For this purpose, a proton has been linked to the nitrogen atom of benzimidazole and calculated their absorption and emission spectrums aqueous phase. The results of the selected T-Zn-T, T-Hg-A, A-Ni-T, C-Pt-G, G-Pt-C and $\mathrm{C}-\mathrm{Ni}-\mathrm{C}$ base pairs have been given in the Table 7 and Table 8.

Examination of the tables show that T-Hg-A, A-Ni-T, C-Pt-G, C-Ni-C base pairs represents an OR logic gate, while T-Zn-T, G-Pt-C produces AND gate and XOR gate, respectively. In the AND gate for $\mathrm{T}-\mathrm{Zn}-\mathrm{T}$ pair, fluorescence takes 
Table 7. Logic Gates for T-T, T-A, A-T base pairs and their complexes with Bnz.

\begin{tabular}{|c|c|c|c|c|c|c|c|c|c|c|}
\hline Pairs & $\begin{array}{l}\lambda \mathrm{Abs} \\
(\mathrm{nm})\end{array}$ & $\begin{array}{c}\lambda \mathrm{Ems} \\
(\mathrm{nm})\end{array}$ & $\begin{array}{c}\Delta \lambda \\
(\mathrm{nm})\end{array}$ & $\begin{array}{c}\text { Input } \\
\mathrm{H}^{+}\end{array}$ & $\begin{array}{c}\text { Input } \\
\mathrm{Zn}^{+}\end{array}$ & $\begin{array}{c}\text { Input } \\
\mathrm{Hg}^{2+}\end{array}$ & $\begin{array}{l}\text { Input } \\
\mathrm{Ni}^{+}\end{array}$ & Output AND & $\begin{array}{c}\text { Output } \\
\text { OR }\end{array}$ & $\begin{array}{c}\lambda \operatorname{Max} \\
(\mathrm{nm})\end{array}$ \\
\hline T-T-Bnz & 319 & 337 & 18.23 & 0 & 0 & & & 0 & & 337.73 \\
\hline $\mathrm{T}-\mathrm{H}^{+}-\mathrm{T}-\mathrm{Bnz}$ & 517 & 531 & 24.81 & 1 & 0 & & & 0 & & 531.34 \\
\hline T-Zn-T-Bnz & 468 & 482 & 13.60 & 0 & 1 & & & 0 & & 482.10 \\
\hline \multirow[t]{2}{*}{$\mathrm{T}-\mathrm{Zn}, \mathrm{H}^{+}-\mathrm{T}-\mathrm{Bnz}$} & 843 & 912 & 91.02 & 1 & 1 & & & 1 & & 912.80 \\
\hline & & & & & & & & & 0 & \\
\hline T-A-Bnz & 334 & 357 & 22.87 & 0 & & 0 & & & 1 & 357.04 \\
\hline $\mathrm{T}-\mathrm{H}^{+}-\mathrm{A}-\mathrm{Bnz}$ & 412 & 431 & 54.18 & 1 & & 0 & & & 1 & 431.13 \\
\hline T-Hg-A-Bnz & 468 & 509 & 41.68 & 0 & & 1 & & & 1 & 509.08 \\
\hline $\mathrm{T}-\mathrm{Hg}, \mathrm{H}^{+}-\mathrm{A}-\mathrm{Bnz}$ & 574 & 581 & 73.20 & 1 & & 1 & & & & 581.34 \\
\hline A-T-Bnz & 365 & 404 & 38.69 & 0 & & & 0 & & 0 & 404.40 \\
\hline $\mathrm{A}-\mathrm{H}^{+}-\mathrm{T}-\mathrm{Bnz}$ & 487 & 356 & 43.26 & 1 & & & 0 & & 1 & 536.38 \\
\hline A-Ni-T-Bnz & 443 & 661 & 217.40 & 0 & & & 1 & & 1 & 661.20 \\
\hline $\mathrm{A}-\mathrm{Ni}, \mathrm{H}^{+}-\mathrm{T}-\mathrm{Bnz}$ & 364 & 381 & 57.05 & 1 & & & 1 & & 1 & 381.09 \\
\hline
\end{tabular}

Table 8. Logic Gates for C-G, G-C, C-C base pairs and their complexes with Bnz.

\begin{tabular}{|c|c|c|c|c|c|c|c|c|c|}
\hline Pairs & $\begin{array}{c}\lambda \mathrm{Abs} \\
(\mathrm{nm})\end{array}$ & $\begin{array}{c}\lambda \mathrm{Ems} \\
(\mathrm{nm})\end{array}$ & $\begin{array}{c}\Delta \lambda \\
(\mathrm{nm})\end{array}$ & $\begin{array}{c}\text { Input } \\
\mathrm{H}^{+}\end{array}$ & Input $\mathrm{Pt}^{+}$ & $\begin{array}{l}\text { Input } \\
\mathrm{Ni}^{+}\end{array}$ & Output OR & $\begin{array}{c}\text { Output } \\
\text { XOR }\end{array}$ & $\begin{array}{c}\lambda \operatorname{Max} \\
(\mathrm{nm})\end{array}$ \\
\hline C-G-Bnz & 297 & 310 & 13.77 & 0 & 0 & & 0 & & 310.80 \\
\hline $\mathrm{C}-\mathrm{H}^{+}-\mathrm{G}-\mathrm{Bnz}$ & 363 & 401 & 74.43 & 1 & 0 & & 1 & & 401.06 \\
\hline C-Pt-G-Bnz & 439 & 663 & 194.76 & 0 & 1 & & 1 & & 663.76 \\
\hline $\mathrm{C}-\mathrm{Pt}, \mathrm{H}^{+}-\mathrm{G}-\mathrm{Bnz}$ & 812 & 940 & 217.60 & 1 & 1 & & 1 & & 940.62 \\
\hline G-C-Bnz & 279 & 290 & 10.38 & 0 & 0 & & & 0 & 290.03 \\
\hline $\mathrm{G}-\mathrm{H}^{+}-\mathrm{C}-\mathrm{Bnz}$ & 964 & 1012 & 148.90 & 1 & 0 & & & 1 & 1012.1 \\
\hline G-Pt-C-Bnz & 403 & 615 & 212.16 & 0 & 1 & & & 1 & 615.2 \\
\hline $\mathrm{G}-\mathrm{Pt}, \mathrm{H}^{+}-\mathrm{C}-\mathrm{Bnz}$ & 321 & 340 & 29.03 & 1 & 1 & & & 0 & 340.6 \\
\hline C-C-Bnz & 343 & 374 & 31.53 & 0 & & 0 & & & 374.60 \\
\hline $\mathrm{C}-\mathrm{H}^{+}-\mathrm{C}-\mathrm{Bnz}$ & 363 & 382 & 37.66 & 1 & & 0 & & & 382.17 \\
\hline C-Ni-C-Bnz & 414 & 635 & 220.34 & 0 & & 1 & & & 635.24 \\
\hline $\mathrm{C}-\mathrm{Ni}, \mathrm{H}^{+}-\mathrm{C}-\mathrm{Bnz}$ & 276 & 616 & 89.47 & 1 & & 1 & & & 316.43 \\
\hline
\end{tabular}

place when the proton and the $\mathrm{Zn}^{2+}$ cation available in the system at the same time. XOR gate for G-Pt-C occurs in the event of being proton or $\mathrm{Pt}^{2+}$ cation. For the afore-mentioned other base pairs have shown OR logic gateand it means that fluorescence can be seen when the metal cation, proton and both of them are in the system.

Also, bonding of metal cation and protonation of selected pairs has been caused to red shift in absorption spectrum as well as emission spectrum for all the interested base pairs. C-Ni-C-Bnz pair shows the most largest Stokes shift among the molecules that have been selected for logic gates calculations. The $\mathrm{C}$ 
and $\mathrm{G}$ base pairs have higher Stokes shift values than the thymine and adenine pairs.

\section{Conclusion}

In this study, we have theoretically studied complexation energies, their band gap and electronic absorption-emission spectral behaviors of targeted DNA base pairs in the water phase. In order to determine the appropriate method for UV-vis absorption wavelength maxima of pairs, it has been calculated with three different functionals and compared with the experimental data and each other. Results show that M06/Lanl2dz level is good agreement with experimental absorption wavelength. The energy calculation results give that all the base pairs primarily prefer $\mathrm{Ni}^{2+}$ cation for complexation, whereas $\mathrm{A}-\mathrm{T}$ base pairs prefer $\mathrm{Hg}^{2+}$ cation. The same trend has been observed in case of being benzimidazole in pairs. HOMO-LUMO band gap results have shown that the resonance stability increased with $\mathrm{Hg}^{2+}, \mathrm{Ag}^{+}$and $\mathrm{Zn}^{2+}$ cations, while the $\mathrm{Pt}^{2+}$ and $\mathrm{Pd}^{2+}$ provide thermodynamically stable. Our calculated electronic spectrum presents that designed DNA base pairs can be use as a probe to detected selected cations. The fluorescence of C-G, G-C pairs answers for $\mathrm{Pt}^{2+} \mathrm{Pd}^{2+}$ and $\mathrm{Zn}^{2+}$ cations, while T-T, T-A and A-T are given for $\mathrm{Hg}^{2+}, \mathrm{Ag}^{+}$and $\mathrm{Zn}^{2+}$ cations. The calculated results for their logic gates have been given that addition of protons to designed DNA pairs causes a red shift for all pairs in the water phase. Also, the presence of metal cations causes a red shift like protonation, except for $\mathrm{Ni}^{2+}$ cation. As a result of calculated absorption-emission spectrum data show that T-Hg-A-Bnz, A-Ni-T-Bnz, C-Pt-G-Bnz, C-Ni-C-Bnz complexes produce OR gate. T-Zn-T$\mathrm{Bnz}$ and G-Pt-C-Bnz results demonstrated XOR and AND logic gate, respectively. In brief, this theoretical study manifestes important electronic and photophysical behaviors of designed metallo-DNA pairs which can be use to determining of selected cations.

\section{Acknowledgements}

We acknowledge the support of TUBITAK (Scientific and Technical Research Council of the Turkish Republic) under grant no. 214Z022.

\section{References}

[1] Holliday, B.J. and Mirkin, C.A. (2001) Strategies for the Construction of Supramolecular Compounds through Coordination Chemistry. Angewandte Chemi, 40, 2022-2043.

http://dx.doi.org/10.1002/1521-3773(20010601)40:11<2022::AID-ANIE2022>3.0.C $\mathrm{O} ; 2-\mathrm{D}$

[2] Panja, K.S., Dwivedi, N. and Saha, S. (2016) Highly Stable Naphthalene Core Based Novel Cleftshaped Strain Molecule: Influence of Intermolecular H-Bonding Architectures. The Royal Society of Chemistry, 6, 59574-59581. http://dx.doi.org/10.1039/c6ra06855c

[3] Mahmudov, K.T., Kopylovich, M.N., Silva, F.C. and Pombeiro, A.J.L. (2016) NonCovalent İnteractions in the Synthesis of Coordination Compounds: Recent Ad- 
vances. Coordination Chemistry Reviews.

http://dx.doi.org/10.1016/j.ccr.2016.09.002

[4] Hisamatsu, Y., Miyazawa, Y., Yoneda, K., Miyauchi, M., Zulkefeli, M. and Aoki, S. (2016) Supramolecular Complexes Formed by the Self-Assembly of Hydrophobic Bis(Zn2+-cyclen) Complexes, Copper, and Di- or Triimide Units for the Hydrolysis of Phosphate Mono- and Diesters in Two-Phase Solvent Systems (Cyclen = 1,4,7,10Tetraazacyclododecane). Chemical and Pharmaceutical Bulletin, 64, 451-464. http://dx.doi.org/10.1248/cpb.c15-01014

[5] Smith, S.J., Radford, R.J., Subramanian, R.H., Barnett, B.R., Figueroa, J.S. and Tezcan, F.A. (2016) Tunable Helicity, Stability and DNA-Binding Properties of Short Peptides with Hybrid Metal Coordination Motifs. Chemical Science, 7, 5453-5461. http://dx.doi.org/10.1039/c6sc00826g

[6] Santamaria-Diaz, N., Mendez-Arriaga, M.J., Salas, J.M. and Galindo, M.A. (2016) Highly Stable Double-Stranded DNA Containing Sequential Silver (I)-Mediated 7-Deazaadenine/Thymine Watson-Crick Base Pairs. Angewandte Chemie, 55, 6170-6174. http://dx.doi.org/10.1002/anie.201600924

[7] Léon, J.C., Sinha, I. and Müller, J. (2016) 6-Pyrazolylpurine as an Artificial Nucleobase for Metal-Mediated Base Pairing in DNA Duplexes. International Journal of Molecular Sciences, 17, 554-564. http://dx.doi.org/10.3390/ijms17040554

[8] Camacho, C.C., Ruiz, A.E., Hueso P.A., Mijangos, E., Garcia, I.R., Contreras, R. and Parra, A.F. (2013) Organometallic Tin Compounds Derived from 2-Benzimidazole Propionic Acid. Zeitschrift für anorganische und allgemeine Chemie, 7, 1122-1128. http://dx.doi.org/10.1002/zaac.201300108

[9] Mallajosyula, S.S. and Pati, S.K. (2008) Benzimidazole-Modified Single-Stranded DNA: Stable Scaffolds for 1-Dimensional Spintronics Constructs. Journal of Physical. Chemistry B, 112, 16982-16989. http://dx.doi.org/10.1021/jp8080782.

[10] Miyake, Y., Togashi, M., Tashiro, M., Yamaguchi, H., Oda, S., Kudo, M., Tanaka, Y., Kondo, Y., Sawa, R., Fujimoto, T., Machinami, T. and Ono, A. (2005) Mercury ${ }^{\mathrm{II}}$-Mediated Formation of Thymine-Hg ${ }^{\mathrm{II}}$-Thymine Base Pairs in DNA Duplexes. Journal of the American Chemical Society, 128, 2172-2173. http://dx.doi.org/10.1021/ja056354d

[11] Miyachi, H., Matsui, T., Shigetac, Y. and Hirao, K. (2009) Effects of Mercury (II) on Structural Properties, Electronic Structure and UV Absorption Spectra of a Duplex Containing Thymine-Mercury(II)-Thymine Nucleobase Pairs. Physical Chemistry Chemical Physics, 12, 909-917. https://doi.org/10.1039/B912807G

[12] Takezawa, Y. and Shionoya, M. (2012) Metal-Mediated DNA Base Pairing: Alternatives to Hydrogen-Bonded Watson Crick Base Pairs. Accounts of Chemical Research, 45, 2066-2076. https://doi.org/10.1021/ar200313h

[13] Wu, J., Fu, Y., He, Z., Han, Y., Zheng, L., Zhang, J. and Li, W. (2012) Growth Mechanisms of Fluorescent Silver Clusters Regulated by Polymorphic DNA Templates: A DFT Study. The Journal of Physical Chemistry B, 116, 1655-1665. https://doi.org/10.1021/jp206251v

[14] Müller, A., Talbot, F. and Leutwyler, S. (2002) Hydrogen Bond Vibrations of 2Aminopyridineâ2-Pyridone, Watson-Crick Analogue of Adenine Uracil. Journal of the American Chemical Society, 124, 14486-14494. https://doi.org/10.1021/ja0209969

[15] Brown, G.J. (2004) Encyclopedia of Supramolecular Chemistry. In: Atwood, J.L. and Steed, J.W., Eds., Encyclopedia of Supramolecular Chemistry, CRC Press, Taylor and Francis Group, New York, 893.

[16] Kubo, K. (2005) PET Sensors. In: Geddes, C.D. and Lakowicz, J.R., Eds., Topics in 
Fluorescence Spectroscopy: Advanced Concepts in Fluorescence Sensing, Springer Science Business Media, New York, 241.

[17] Frisch, M.J., Trucks, G.W., Schlegel, H.B., Scuseria, G.E., Robb, M.A., Cheeseman, J.R., Scalmani, G., Barone, V., Mennucci, B., Petersson, G.A., Nakatsuji, H., Caricato, M., Li, X., Hratchian, H.P., Izmaylov, A.F., Bloino, J., Zheng, G., Sonnenberg, J.L., Hada, M., Ehara, M., Toyota, K., Fukuda, R., Hasegawa, J., Ishida, M., Nakajima, T., Honda, Y., Kitao, O., Nakai, H., Vreven, T., Montgomery, J.A., Peralta, J.E., Ogliaro, F., Bearpark, M., Heyd, J.J., Brothers, E., Kudin, K.N., Staroverov, V.N., Kobayashi, R., Normand, J., Raghavachari, K., Rendell, A., Burant, J.C., Iyengar, S.S., Tomasi, J., Cossi, M., Rega, N., Millam, J.M., Klene, M., Knox, J.E., Cross, J.B., Bakken, V., Adamo, C., Jaramillo, J., Gomperts, R., Stratmann, R.E., Yazyev, O., Austin, A.J., Cammi, R., Pomelli, C., Ochterski, J.W., Martin, R.L., Morokuma, K., Zakrzewski, V.G., Voth, G.A., Salvador, P., Dannenberg, J.J., Dapprich, S., Daniels, A.D., Farkas, Ö., Foresman, J.B., Ortiz, J.V., Cioslowski, J. and Fox, D.J. (2009) Gaussian 09, Revision E.01. Gaussian Inc., Wallingford.

[18] Dennington, R., Keith, T. and Millam, J. (2009) Gauss View.

[19] Zhang, B., Ma, P., Gao, D., Wang, Z., Sun, Y., Song, D. and Li, X. (2016) A FRET-Based Fluorescent Probe Formercury Ions in Water and Living Cells. Spectrochimica Acta Part A: Molecular and Biomolecular Spectroscopy, 165, 99105.

[20] Sicilia, V., Borja, P., Bayab, M. and Casasb, J. (2015) Selective Turn-Off Phosphorescent and Colorimetric Detection of Mercury (II) in Water ByhalfLantern Platinum(II) Complexes. Dalton Transactions, 44, 6936-6943. https://doi.org/10.1039/C5DT00087D

[21] Karhu, A., Rautiainen, M., Oilunkaniemi, R., Chivers, T. and Laitinen, R. (2015) Mercury- and Cadmium-Assisted [2 + 2] Cyclodimerization of Tert-Butylselenium Diimide. Inorganic Chemistry, 54, 9499-9508. https://doi.org/10.1021/acs.inorgchem.5b01434

[22] Zhao, Y. and Truhlar, D.G. (2006) The M06 Suite of Density Functionals for Main Group Thermochemistry, Thermochemical Kinetics, Noncovalent Interactions, Excited States and Transition Elements: Two New Functionals and Systematic Testing of Four M06-Class Functionals and 12 Other Functionals. Theoretical Chemistry Accounts, 120, 215-241. https://doi.org/10.1007/s00214-007-0310-x

[23] Rives, J.T. and Jorgensen, W.L. (2008) Performance of B3LYP Density Functional Methods for a Large Set of Organic Molecules. Journal of Chemical Theory and Computation, 4, 297-306. https://doi.org/10.1021/ct700248k

[24] Adamo, C. and Barone, V. (1999) Toward Reliable Density Functional Methods without Adjustable Parameters: The PBE0 Model. The Journal of Chemical Physics, 113, 6158-6170. https://doi.org/10.1063/1.478522

[25] Chiodo, S., Russo, N. and Sicilia, E. (2006) LANL2DZ Basis Sets Recontracted in the Framework Of Density Functional Theory. The Journal of Chemical Physics, 125, 104-107. https://doi.org/10.1063/1.2345197

[26] Klamt, A. (1994) Conductor-Like Screening Model for Real Solvents: A New Approach to the Quantitative Calculation of Solvation Phenomena. The Journal of Physical Chemistry, 99, 2224-2235. https://doi.org/10.1021/j100007a062

[27] http://www.gaussian.com/g_tech/g_ur/k_scrf.htm 


\section{Supplementary Tables}

Table S1. HOMO-LUMO molecular orbital energies and complexation energies in eV for T-Hg-T, calculated with MO6, B3LYP and PBE0 method (Kcal/mol).

\begin{tabular}{cccccccc}
\hline \multirow{2}{*}{ Methods } & \multicolumn{7}{c}{ T-Hg-T } \\
\cline { 2 - 8 } & HOMO & LUMO & $\Delta$ Gap (L-H) & $\Delta \mathrm{G}$ & $\Delta \mathrm{H}$ & $\Delta \mathrm{E}$ & Absorbance \\
\hline \multirow{2}{*}{ B3LYP } & -6.46 & -1.15 & 5.30 & -595906.58 & -595862.38 & -595874.80 & 269.34 \\
PBE0 & -5.56 & -1.78 & 5.78 & -595417.20 & -595373.64 & -595386.05 & 331.99 \\
M06 & -6.76 & -0.95 & 5.81 & -595556.71 & -595513.17 & -595525.35 & 264.48 \\
\hline
\end{tabular}

Table S2. The complexation energies of thymine-thymine (T-T), thymine-adenine (T-A) base pairs with metal cations (Kcal/mol).

\begin{tabular}{|c|c|c|c|c|c|c|c|}
\hline \multirow{2}{*}{ Base Pairs } & \multicolumn{7}{|c|}{ Energy Values } \\
\hline & $\Delta \mathrm{E}$ & $\Delta \mathrm{G}$ & $\Delta \mathrm{H}$ & Base Pairs & $\Delta \mathrm{E}$ & $\Delta \mathrm{G}$ & $\Delta \mathrm{H}$ \\
\hline $\mathrm{T}-\mathrm{T} \rightarrow \mathrm{T}-\mathrm{Hg}-\mathrm{T}$ & -113.11 & -122.66 & -122.64 & $\mathrm{~T}-\mathrm{A} \rightarrow \mathrm{T}-\mathrm{Hg}-\mathrm{A}$ & -97.02 & -101.32 & 95.98 \\
\hline $\mathrm{T}-\mathrm{T} \rightarrow \mathrm{T}-\mathrm{Zn}-\mathrm{T}$ & -89.06 & -98.06 & -88.49 & $\mathrm{~T}-\mathrm{A} \rightarrow \mathrm{T}-\mathrm{Zn}-\mathrm{A}$ & -77.75 & -81.46 & -77.02 \\
\hline $\mathrm{T}-\mathrm{T} \rightarrow \mathrm{T}-\mathrm{Ag}-\mathrm{T}$ & -69.98 & -78.26 & -69.69 & $\mathrm{~T}-\mathrm{A} \rightarrow \mathrm{T}-\mathrm{Ag}-\mathrm{A}$ & -64.99 & -72.19 & -61.76 \\
\hline $\mathrm{T}-\mathrm{T} \rightarrow \mathrm{T}-\mathrm{Ni}-\mathrm{T}$ & -147.64 & -183.55 & -143.50 & $\mathrm{~T}-\mathrm{A} \rightarrow \mathrm{T}-\mathrm{Ni}-\mathrm{A}$ & -123.26 & -134.85 & -119.63 \\
\hline $\mathrm{T}-\mathrm{T} \rightarrow \mathrm{T}-\mathrm{Pd}-\mathrm{T}$ & -52.12 & -59.08 & -51.23 & $\mathrm{~T}-\mathrm{A} \rightarrow \mathrm{T}-\mathrm{Pd}-\mathrm{A}$ & -47.78 & -50.00 & -47.22 \\
\hline $\mathrm{T}-\mathrm{T} \rightarrow \mathrm{T}-\mathrm{Pt}-\mathrm{T}$ & -63.41 & -71.98 & -61.54 & $\mathrm{~T}-\mathrm{A} \rightarrow \mathrm{T}-\mathrm{Pt}-\mathrm{A}$ & -56.36 & -61.35 & -54.49 \\
\hline
\end{tabular}

Table S3. The complexation energies of T-T-Bnz and T-A-Bnz base pairs with metal cations (Kcal/mol).

\begin{tabular}{cccccccc}
\hline & \multicolumn{7}{c}{ Energy Values } \\
\hline Base Pairs & $\Delta \mathrm{E}$ & $\Delta \mathrm{G}$ & $\Delta \mathrm{H}$ & Base Pairs & $\Delta \mathrm{E}$ & $\Delta \mathrm{G}$ & $\Delta \mathrm{H}$ \\
\hline T-T-Bnz $\rightarrow$ T-Hg-T-Bnz & -112.91 & -112.08 & -112.53 & T-A-Bnz $\rightarrow$ T-Hg-A-Bnz & -97.02 & -96.05 & -94.01 \\
T-T-Bnz $\rightarrow$ T-Zn-T-Bnz & -89.37 & -99.02 & -88.62 & T-A-Bnz $\rightarrow$ T-Zn-A-Bnz & -77.75 & -77.00 & -75.67 \\
T-T-Bnz $\rightarrow$ T-Ag-T-Bnz & -70.01 & -79.37 & -69.91 & T-A-Bnz $\rightarrow$ T-Ag-A-Bnz & -64.99 & -64.22 & -60.80 \\
T-T-Bnz $\rightarrow$ T-Ni-T-Bnz & -147.98 & -184.62 & -143.72 & T-A-Bnz $\rightarrow$ T-Ni-A-Bnz & -123.26 & -122.41 & -121.33 \\
T-T-Bnz $\rightarrow$ T-Pd-T-Bnz & -52.18 & -60.81 & -51.39 & T-A-Bnz $\rightarrow$ T-Pd-A-Bnz & -47.78 & -45.89 & -45.46 \\
T-T-Bnz $\rightarrow$ T-Pt-T-Bnz & -63.74 & -73.26 & -62.35 & T-A-Bnz $\rightarrow$ T-Pt-A-Bnz & -56.36 & -56.00 & -55.03
\end{tabular}

Table S4. The complexation energies of A-T-Bnz base pairs with metal cations (Kcal/mol).

\begin{tabular}{cccc}
\hline Base Pairs & \multicolumn{3}{c}{ Energy Values } \\
\cline { 2 - 4 } & $\Delta \mathrm{E}$ & $\Delta \mathrm{G}$ & -98.88 \\
\hline A-T-Bnz $\rightarrow$ A-Hg-T-Bnz & -101.11 & -105.22 & -83.00 \\
A-T-Bnz $\rightarrow$ A-Zn-T-Bnz & -83.10 & -84.92 & -69.77 \\
A-T-Bnz $\rightarrow$ A-Ag-T-Bnz & -71.26 & -76.00 & -100.00 \\
A-T-Bnz $\rightarrow$ A-Ni-T-Bnz & -102.95 & -104.55 & -50.13 \\
A-T-Bnz $\rightarrow$ A-Pd-T-Bnz & -51.01 & -54.02 & -63.06 \\
A-T-Bnz $\rightarrow$ A-Pt-T-Bnz & -63.53 & -67.26 & - \\
\hline
\end{tabular}


Table S5. The colour changes of of T-T, T-A, A-T and their complexes with Bnz and metal cations.

\begin{tabular}{|c|c|c|c|c|c|}
\hline T-M-T & B.L & A.L & T-M-T-Bnz & B.L & A.L \\
\hline $\mathrm{T}-\mathrm{T}$ & - & - & T-T-Bnz & - & - \\
\hline T-Hg-T & - & - & T-Hg-T-Bnz & - & Violet \\
\hline T-Zn-T & Blue & Blue & T-Zn-T-Bnz & Blue & Green \\
\hline T-Ag-T & Yellow & - & T-Ag-T-Bnz & - & - \\
\hline T-Ni-T & - & - & T-Ni-T-Bnz & - & - \\
\hline T-Pd-T & - & - & T-Pd-T-Bnz & - & - \\
\hline T-Pt-T & Orange & - & T-Pt-T-Bnz & - & - \\
\hline T-M-A & B.L & A.L & T-M-A-Bnz & B.L & A.L \\
\hline T-A & - & - & T-A-Bnz & - & - \\
\hline T-Hg-A & Blue & Green & T-Hg-A-Bnz & Blue & Green \\
\hline T-Zn-A & Yellow & Red & T-Zn-A-Bnz & Red & - \\
\hline T-Ag-A & Red & - & T-Ag-A-Bnz & - & - \\
\hline T-Ni-A & - & Blue & T-Ni-A-Bnz & - & Blue \\
\hline T-Pd-A & - & - & T-Pd-A-Bnz & - & - \\
\hline T-Pt-A & - & - & T-Pt-A-Bnz & - & - \\
\hline A-M-T & B.L & A.L & A-M-T-Bnz & B.L & A.L \\
\hline $\mathrm{A}-\mathrm{T}$ & - & - & A-T-Bnz & - & Violet \\
\hline A-Hg-T & Blue & Green & A-Hg-T-Bnz & Violet & Green \\
\hline$A-Z n-T$ & Yellow & Red & A-Zn-T-Bnz & Red & Red \\
\hline A-Ag-T & Red & - & A-Ag-T-Bnz & - & - \\
\hline A-Ni-T & - & Blue & A-Ni-T-Bnz & Violet & Red \\
\hline A-Pd-T & - & - & A-Pd-T-Bnz & - & - \\
\hline A-Pt-T & - & - & A-Pt-T-Bnz & - & - \\
\hline
\end{tabular}

B.L: Before luminescence; A.L: After luminescence

Table S6. The complexation energies of C-G and C-C base pairs with metal cations (Kcal/mol).

\begin{tabular}{cccccccc}
\hline \multirow{2}{*}{ Base Pairs } & \multicolumn{7}{c}{ Energy Values } \\
\cline { 2 - 8 } & $\Delta \mathrm{E}$ & $\Delta \mathrm{G}$ & $\Delta \mathrm{H}$ & Base Pairs & $\Delta \mathrm{E}$ & $\Delta \mathrm{G}$ & $\Delta \mathrm{H}$ \\
\hline C-G $\rightarrow$ C-Hg-G & -137.74 & -140.33 & -135.80 & C-C $\rightarrow$ C-Hg-C & -88.10 & -91.33 & -85.90 \\
C-G $\rightarrow$ C-Zn-G & -62.16 & -63.55 & -60.06 & C-C $\rightarrow$ C-Zn-C & -81.07 & -82.22 & -79.56 \\
C-G $\rightarrow$ C-Ag-G & -75.82 & -77.77 & -75.10 & C-C $\rightarrow$ C-Ag-C & -93.00 & -94.27 & -89.90 \\
C-G $\rightarrow$ C-Ni-G & -151.04 & -154.64 & -149.86 & C-C $\rightarrow$ C-Ni-C & -108.75 & -110.01 & -107.00 \\
C-G $\rightarrow$ C-Pd-G & -97.76 & -101.04 & -95.55 & C-C $\rightarrow$ C-Pd-C & -77.42 & -80.00 & -76.20 \\
C-G $\rightarrow$ C-Pt-G & -110.26 & -113.36 & -109.55 & C-C $\rightarrow$ C-Pt-C & -79.55 & -79.88 & -76.59 \\
\hline
\end{tabular}

Table S7. The complexation energies of C-G -Bnz and G-C-Bnz base pairs with metal cations (Kcal/mol).

\begin{tabular}{|c|c|c|c|c|c|c|c|}
\hline \multirow{2}{*}{ Base Pairs } & \multicolumn{7}{|c|}{ Energy Values } \\
\hline & $\Delta \mathrm{E}$ & $\Delta \mathrm{G}$ & $\Delta \mathrm{H}$ & Base Pairs & $\Delta \mathrm{E}$ & $\Delta \mathrm{G}$ & $\Delta \mathrm{H}$ \\
\hline C-G-Bnz $\rightarrow$ C-Hg-G-Bnz & -124.05 & -125.05 & -123.86 & G-C-Bnz $\rightarrow$ G-Hg-CBnz & -130.99 & -132.45 & -128.94 \\
\hline C-G-Bnz $\rightarrow$ C-Zn-G-Bnz & -61.04 & -61.04 & -58.97 & $\mathrm{G}-\mathrm{C}-\mathrm{Bnz} \rightarrow \mathrm{G}-\mathrm{Zn}-\mathrm{C}-\mathrm{Bnz}$ & -66.11 & -69.01 & -64.89 \\
\hline C-G-Bnz $\rightarrow$ C-Ag-G-Bnz & -73.24 & -73.24 & -73.00 & G-C-Bnz $\rightarrow$ G-Ag-C-Bnz & -79.05 & -81.34 & -78.22 \\
\hline C-G-Bnz $\rightarrow$ C-Ni-G-Bnz & -147.69 & -147.69 & -146.11 & G-C-Bnz $\rightarrow$ G-Ni-C-Bnz & -148.27 & -150.09 & -148.00 \\
\hline C-G-Bnz $\rightarrow$ C-Pd-G-Bnz & -94.26 & -94.26 & -92.50 & G-C-Bnz $\rightarrow$ G-Pd-C-Bnz & -96.13 & -99.58 & -94.99 \\
\hline C-G-Bnz $\rightarrow$ C-Pt-G-Bnz & -104.97 & -104.97 & -104.00 & G-C-Bnz $\rightarrow$ G-Pt-C-Bnz & -108.60 & -110.78 & -108.01 \\
\hline
\end{tabular}


Table S8. The complexation energies of C-C-Bnz base pairs with metal cations (Kcal/mol).

\begin{tabular}{cccc}
\hline & \multicolumn{3}{c}{ Energy Values } \\
\cline { 2 - 4 } Base Pairs & $\Delta \mathrm{E}$ & $\Delta \mathrm{G}$ & $\Delta \mathrm{H}$ \\
\hline C-C-Bnz $\rightarrow$ C-Hg-CBnz & -130.99 & -132.45 & -128.94 \\
C-C-Bnz $\rightarrow$ C-Zn-C-Bnz & -66.11 & -69.01 & -64.89 \\
C-C-Bnz $\rightarrow$ C-Ag-C-Bnz & -79.05 & -81.34 & -78.22 \\
C-C-Bnz $\rightarrow$ C-Ni-C-Bnz & -148.27 & -150.09 & -148.00 \\
C-C-Bnz $\rightarrow$ C-Pd-C-Bnz & -96.13 & -99.58 & -94.99 \\
C-C-Bnz $\rightarrow$ C-Pt-C-Bnz & -108.60 & -110.78 & -108.01 \\
\hline
\end{tabular}

Table S9. The colour changes of of C-G, G-C, C-C and their complexes with Bnz and metal cations.

\begin{tabular}{|c|c|c|c|c|c|}
\hline C-M-G & B.L & A.L & C-M-G-Bnz & B.L & A.L \\
\hline $\mathrm{C}-\mathrm{G}$ & - & - & C-G-Bnz & - & - \\
\hline $\mathrm{C}-\mathrm{Hg}-\mathrm{G}$ & - & Blue & C-Hg-G-Bnz & - & Blue \\
\hline C-Zn-G & Green & Green & C-Zn-G-Bnz & - & - \\
\hline C-Ag-G & - & - & C-Ag-G-Bnz & - & - \\
\hline $\mathrm{C}-\mathrm{Ni}-\mathrm{G}$ & - & Green & C-Ni-G-Bnz & - & - \\
\hline C-Pd-G & Blue & Green & C-Pd-G-Bnz & Blue & Green \\
\hline C-Pt-G & Blue & - & C-Pt-G-Bnz & Violet & Red- \\
\hline G-M-C & B.L & A.L & C-M-G-Bnz & B.L & A.L \\
\hline G-C & - & - & G-C-Bnz & - & - \\
\hline G-Hg-C & - & Blue & $\mathrm{G}-\mathrm{Hg}-\mathrm{C}-\mathrm{Bnz}$ & - & Yellow \\
\hline $\mathrm{G}-\mathrm{Zn}-\mathrm{C}$ & Green & Green & G-Zn-C-Bnz & - & - \\
\hline G-Ag-C & - & - & G-Ag-C-Bnz & - & - \\
\hline G-Ni-C & - & Green & G-Ni-C-Bnz & - & Violet \\
\hline G-Pd-C & Blue & Green & G-Pd-C-Bnz & Blue & Green \\
\hline G-Pt-C & Blue- & -- & G-Pt-C-Bnz & Violet & Orange- \\
\hline C-M-C & B.L & A.L & C-M-C-Bnz & B.L & A.L \\
\hline $\mathrm{C}-\mathrm{C}$ & - & Violet & C-C-Bnz & - & - \\
\hline C-Hg-C & Red & - & C-Hg-C-Bnz & Red & - \\
\hline C-Zn-C & - & - & C-Zn-C-Bnz & - & - \\
\hline C-Ag-C & Red & - & C-Ag-C-Bnz & Red & - \\
\hline $\mathrm{C}-\mathrm{Ni}-\mathrm{C}$ & Violet & - & C-Ni-C-Bnz & Violet & Orange \\
\hline C-Pd-C & - & - & C-Pd-C-Bnz & - & - \\
\hline C-Pt-C & - & - & C-Pt-C-Bnz & -- & - \\
\hline
\end{tabular}


Submit or recommend next manuscript to SCIRP and we will provide best service for you:

Accepting pre-submission inquiries through Email, Facebook, LinkedIn, Twitter, etc. A wide selection of journals (inclusive of 9 subjects, more than 200 journals)

Providing 24-hour high-quality service

User-friendly online submission system

Fair and swift peer-review system

Efficient typesetting and proofreading procedure

Display of the result of downloads and visits, as well as the number of cited articles Maximum dissemination of your research work

Submit your manuscript at: http://papersubmission.scirp.org/

Or contact cc@scirp.org 